\title{
GENDER ANALYSIS OF CHILD INVESTMENT AND CHILD QUALITY AMONG FARMER FAMILIES IN INDONESIA
}

\author{
Herien Puspitawati ${ }^{1 *}$, Ma'mun Sarma ${ }^{2}$, Elmanora $^{3}$, Yasmin Azizah $^{1}$ \\ ${ }^{1}$ Department of Family and Consumer Sciences, Faculty of Human Ecology, \\ IPB University, Bogor 16680, Indonesia \\ ${ }^{2}$ Department of Management, Faculty of Economics and Management, \\ IPB University, Bogor 16680, Indonesia \\ ${ }^{3}$ Family Welfare Education, Faculty of Engineering, \\ Universitas Negeri Jakarta, Jakarta 13220, Indonesia \\ *)E-mail: herien_puspitawati@email.com
}

\begin{abstract}
Families have obligations to protect and care for their children. The general objective of this study was to analyze the gender of the investment and the quality of the children in highland farmers. The study was conducted at highland areas at Cianjur Regency (Sindangjaya Village, Cipanas Sub-district) and Bogor Regency (Petir Village, Dramaga Sub-district). The findings showed that they were 4 (four) indicators of child investment latent variable such as the allocation of time togetherness between parents and children, investment in education and health, material allocations, and protection of children. Moreover, there were 5 (five) indicators of child quality latent variable such as the physical quality, learning achievement, child's behavior, psycho-social-spiritual, and the quality of life. The first result showed that there was no difference between boys and girls in total of child investment, but there was significantly difference between boys and girls in total of child quality. The second result proved that the latent variable of child investment has significantly positive effect on latent variable of child quality. As recommendation, the study need to be continued with various family characteristics and broadening analysis such as the effect of child investment and child quality to the child happiness.
\end{abstract}

Keywords: child investment, child quality, family, gender, highland farmer

\section{Analisis Gender berdasarkan Investasi Anak dan Kualitas Anak pada Keluarga Petani di Indonesia}

\begin{abstract}
Abstrak
Keluarga memiliki kewajiban untuk melindungi dan merawat anak-anaknya. Tujuan dari penelitian ini adalah untuk melakukan analisis gender berdasarkan investasi dan kualitas anak pada keluarga petani dataran tinggi. Penelitian dilakukan di daerah dataran tinggi di Kabupaten Cianjur (Desa Sindangjaya, Kecamatan Cipanas) dan Kabupaten Bogor (Desa Petir, Kecamatan Dramaga). Temuan menunjukkan bahwa terdapat empat indikator pada variabel laten investasi anak seperti alokasi waktu bersama antara orang tua dan anak-anak, investasi dalam pendidikan dan kesehatan, alokasi materi, dan perlindungan anak. Selain itu, ada lima indikator pada variabel laten kualitas anak seperti kualitas fisik, prestasi belajar, perlaku anak, keadaan psiko-sosial-spiritual dan kualitas hidup anak. Hasil pertama menunjukkan bahwa tidak ada perbedaan dalam investasi anak antara siswa laki-laki dan perempuan, namun ada perbedaan dalam kualitas anak antara laki-laki dan perempuan. Hasil penelitian kedua membuktikan bahwa variabel laten investasi anak berpengaruh positif signifikan terhadap variabel laten kualitas anak. Sebagai rekomendasi adalah perlunya meneruskan penelitian pada berbagai karakteristik keluarga dan meluaskan analisis misalnya analisis pengaruh investasi anak dan kualitas anak terhadap kebahagiaan anak.
\end{abstract}

Kata kunci: gender, investasi anak, keluarga, kulitas anak, petani dataran tinggi

\section{INTRODUCTION}

The study of child investment and child quality is needed in Indonesia, especially among farmer families. This need dues of changes family life in Indonesia over the last decade.
The trend of many problem issues arise, including asocial and criminal problem (criminal mischief, obscene, promiscuity), cultural issues (loss of identity, impact of western culture), and moral degradation problems (lack of respect for others, dishonest to attempt self-harm such as 
drugs, drunkenness and suicide). Furthermore, the quality of children's education such as student achievement, national examination is still very low in most communities, especially in rural areas and in the lower socioeconomic groups (Glewwe \& Jacoby, 1994). In addition, the problem of gender gap in education is significant which interestingly begun in the number of male students who drop out of school and didn't proceed to higher levels (Kemendikbud, 2018).

One of Indonesia's major problems is a high number of poor populations as a result of global economic crisis. Cianjur District is one of the leading sectors of agriculture districts in West Java Province. However, there was 12,2 percent of poor people in Cianjur District at 2013 (BPS, 2014). Approximately 62,9 percent of the population in Cianjur working in the agricultural sector. The problems of economic hardship of the family shown by poverty level will affect the vulnerability of children such as an increase in drop out of basic education (Asmara \& Sukadana, 2017), trafficking (Satriani \& Muis, 2013), domestic violence (Manupahi, Goni, \& Pongoh, 2016), and deviant behavior (Enggarani, 2015). Therefore socioeconomic constraints of the family will lead to limitations in investing activities of children (Arifani, Sari, \& Rifkah, 2018).

Most research studies addressed the need for caring and investing the children within the family especially among the poor family. However, there are only a few studies that address holistically the socialization towards child investment and child quality especially among highland farmer families in Indonesia with a gender analysis approach. This issue supports the need to examine comprehensively socialization towards child investment and child quality among highland farmer families. Thus, child investment could be viewed as an "entry point" in poverty alleviation strategies through the strengthening the family well-being and the increasing of child quality.

Grand theory approach used in this study is the structural-functional theory that emphasizes the family structure and function in developing the quality of human resources (Macionis, 1995; Schwartz \& Scott, 1994; Skidmore, 1979; Spencer \& Inkeles, 1982; Winton, 1995). Family structure in this study included parents and children among highland farmer families in West Java Indonesia. Family functions in this study applied to the "socialization of agricultural and investment activities toward child". As Brown (2006) explained that child investments are manifest in the provision of goods for educational purposes and time spent interacting with children.

According to Holland et al. (Kilpatrick \& Holland, 2003), ecological perspective is dominant in research human behavior in providing for the basic needs of the family and its relationship with the environment. Ecological systems are suitable approach for child to interaction in the family, especially the interaction of parents and children in the cultural and socio-economic change (Haris \& Liebert, 1992). The family is the basic unit of society, a universal environment in which humans learn to eat, walk, and talk, and gain a sense of identity and behavior modes (Coontz, 2000).

The agricultural sector in Indonesia provides food needs of the population, sustains the lives of more than 63 percent of the Indonesian people, provides raw materials for industry, and opens up business opportunities for the population (Chozin et al., 1980). The quality of the Indonesian nation in the future is determined by the quality of the children at this time, including the children of farmers who are still in elementary school. Children of farmers are viewed as nation assets that need to be paid attention on their daily livelihood in the village. That is why the socialization of agricultural environment and investment activities implemented by parents toward their children are considered very important and must be implemented continuously in order to increase child quality and their family wellbeing. As Schultz (1981) said that the child investment will improve economic efficiency and will enhance economic growth in the future.

Families have obligations to protect and care for their children. Referring to the Indonesian Law Number 23 of 2002 on the protection of children, the state guarantees the rights and obligations of each child to be able to live, grow, develop, and participate fairly in accordance with human dignity, as well as protection from violence and discrimination. Every child has the right to have access to education and health facilities at home in the context of child development.

Not many researches have been done in Indonesia with deeply insight by using a gender analysis on socialization of agricultural environment and investment activities implemented by parents toward their children. This research used a gender approach in family studies that highlighted the activities of parents toward their children's investement, children's 
education and health facilities at home. Some concepts are used foundations for this study. According to Bronfenbrenner (1990), the quality of a child's development is determined by microsystem environment consisting of family, peers, school, and neighborhood. Moreover, Merton (Macionis 1995) mentions labeling theory that gives different labels to men and women so that the styles of treatment and care are also different. Although Santrock (2009) states that parents must raise their children to be competent either as a male or a female, not as someone who has a masculine, feminine or androgynous nature. Based on this concepts, this paper emphasizes on the gender analysis of studies child investment implemented by parents and child quality at Cianjur District. Cianjur District was selected for the study because it is a center for the production of vegetables that become the main source for generating income by rural families.

It is strongly believed that to achieve the success of Indonesian nation toward two challenges above, the key to success are prepare quality of human resources who has skill, reliable and civilized as well as possible. The process of the formation of competent human resources starts from the level of the family as the smallest unit of society through the process of investment activities through functions child care and socialization of children, care and protection of children, as well as maintaining the cultural norms noble nation (Rahmiati \& Puspitawati, 2013).

Various definitions of child investment described as follows: (1) focus to the role and commitment as a parent to provide optimal care and attention to the development of children (Greenberger \& Goldberg, 1989); (2) measured by means of multiplication between enrollment rates with the cost of education for one individual, and spending on education and "external" human capital (Lucas, 1988); (3) provision of goods for the purposes of education and time spent interacting with children, investments, measured by total household expenditures non educational items needed, namely, spending on school supplies and tutoring, while parents are used to help learn, read and discuss with the teacher (Brown, 2006). Moreover, Keynes (Bryant, 1990) states that families with higher incomes tend to invest higher in children compared to the low incomes.

Results of previous studies stated the descriptions of the quality of children are: (1) human capital is the most important factor to improve quality of live. Quality of life can be improved by education (Popkova, Chechina, \& Abramov, 2015); (2) quality of life is a person's perception of his position in life, in cultural context and system of values that apply in relation to life and life goals, expectations, standards and concerns (WHO, 1997), and (3) child quality is understood as any child outcome that is valued by the parents. Then, the wellbeing of children can be viewed as their accumulation of human capital. Child quality is multidimensional and related to a child's wellbeing. Indicators of child quality usually measured by educational outcomes (Ponczek \& Souza, 2011).

Research conducted by Kang (2010) found that investment in children is influenced by the number of families. This investment behavior of children is related to the gender. The greater the family size, the lower investment behavior towards girls, which is contrary to investment behavior towards boys. Parents' views about the value of children affect the way families invest in children. Before the family makes an investment in the child, a higher value of the child will affect the investment in the family. When the value of a boys is higher than the investment will be greater in boys, and vice versa if the value of the girls is considered higher than the investment will be greater given to the girls (Hendra, 2018). Research conducted by Villa, Sunarti, and Muflikhati (2020) has different results. This research found that parents make the same investment for both boys and girls.

Michel, Bisegger, Fuhr, and Abel (2009) found that the quality of children has differences based on gender. With increasing age the quality of children in girls' decreases more than in boys. Cavallo et al. (2006) found that the quality of life of girls has a lower level than the quality of life of boys. The low quality of life of girls is caused by perceptions held by girls about their quality of life. In research conducted on adolescents, the quality of life of girls is lower than boys, especially in facing puberty, due to the problems they experience and the coping strategies they use to overcome these problems (Hampel, 2007). Girls generally more worried, and are more sensitive, so they are more prone to psychosomatic disorders and mental complaints that can reduce their quality of life (Nolen-Hoeksema \& Girgus, 1994).

The goal of this research is an attempt to draw up investment instruments and the quality of children who are expected to contribute to addressing the issue of poor quality of human 
resources in most of the younger generation. Policies in optimizing the function of families, especially in children is investing very urgency for the Indonesian nation, especially in achieving the high quality of the child in accordance with the SDG's targets and challenges of globalization and regional decentralization.

This study is expected to be input for the development of investment instruments and the quality of children as consideration for the search for solutions to problems of human resources in Indonesia. It is universally recognized that the role of the family is very important and vital in making investment kid kids to realize high quality of human resources, the human resources have physically tough, mentally strong and vibrant health in addition to the mastery of science and technology. It is assumed that if each family could perform the role and function optimally protect and nurture their children, then it can be ascertained forming an ordered society (in-order society), cultured and dignified (civilized society) as well as prosperous (prosperous society) (Klein \& White, 1996).

This research is attempted to produce a holistic measures of child investment and child quality. Based on the problems of farmer families, two research questions have been proposed as follows: (1) how to measure the index of investment and the quality of children? and (2) what is the effect of child investment on child quality?. The general objective of this study is to implement gender analyze of child investment and child quality in high-land farmer families. The spesific objectives are to: (1) identify the differences of child investment and child quality between boys and girls and (2) analyze the effect of child investment towards child quality.

\section{METHODS}

This research was a preliminary survey and a part of National Priority Research Grants funded by the Ministry of National EducationRepublic of Indonesia Number: 263/E5/2014 with the budget of year 2014-2015. The title of the research was "Gender Analysis of Family Coping Strategies, Investment and Quality of Child in Achieving Targets of Sustainable Development Goals (SDGs) among Highland Farmer Families". This is a descriptive crosssectional study design that examined the conditions of family concerning social and economic characteristics, gender analysis, agricultural socialization towards child and child investments. The interview was conducted from early March to end of May 2014. The study was conducted at highland areas that were selected purposively at two different settlements geographical zones namely Cianjur Regency (Sindangjaya Village, Cipanas Sub-district) and Bogor Regency (Petir Village, Dramaga Subdistrict) which borders the city of Bogor as survey locations, were selected based on a variety of socio-economic conditions of farming families. The site of research was chosen purposively with consideration that Cianjur District is one of the central production areas in vegetables commodities.

The lists of farmer families were taken from the village office administrations to examine the occupation of the families. Samples were chosen from the list of farmer families with school age children, and selected 205 farmer's wives and the children of the 3th to 6th graders boys and girls of elementary school level students. It consisted 120 families from Cianjur District and 85 families from Bogor District), while the gender proportion of the child consisted of 98 boys and 107 girls. The number of respondents from the two regions in this study was different because the respondents were in accordance with the criteria set in the study using this survey method and based on data obtained from the village office.

Several steps were applied to the process of data collections. The first step was the request for permission to begin the procedures from the provincial, district, sub-district, and to village administrative governments. The permission included the proof of ethical clearance that was signed by the Office of Research and Community Services from Bogor Agricultural University. The second step was visiting to the village that was accompanied by the sub-district official with the purpose of socialization of the research purposes and procedures.

A survey instrument was developed to collect the needed data. Once the survey instrument was constructed for this study, the instrument was reviewed for content validity by a national committee/jury for grants competition from the Directorate General of Higher Education, Ministry of Education and Culture-Republic of Indonesia. The committee consisted of national experts in social sciences and faculty members from respected universities in Indonesia. The idea of this paper was also presented at the National Reviewer Committee from the Directorate General of Higher Education, the Ministry of Education and Culture- Republic of Indonesia at December 8, 2013. Section one of 
the instrument focused on the characteristics of farmer families, included the age (by years), the education of all family members (by years), the number of family members (by numbers), the average of monthly income (IDR per month), and the average of monthly expenditures (IDR per month).

The uniqueness of this research was applied multi sources resource person to answer the questions, the wive, and the child in every farmer family. The wive answered the characteristics of the family and child investment variable, whereas the student answered the characteristics of individual and child quality variable.

The instruments referred to the concept of Puspitawati, Sarma, and Yuliati (2015). Index of child iinvestment was assessed by 111 items that were answered by the famers' wives. Child investment is approached by investment on materials, and non-materials including time togetherness. Child investment made by parent at each stage of their child development can affect child skill (Francesconi \& Heckman, 2016). The 111 items were measured on a 2point Likert-type scale ranging from $0=$ no, not applied, 1=yes, applied, for the following dimensions: (a) togetherness of parents and children consisted of 20 items statement, (b) education, health and material investment statement consists of 27 items, (c) protection of children in the physical, psycho-social, socioemotional, and environmental statement consists of 64 items. Child quality is a reflection of quality of the nation and world civilization (Sunarti, 2004). Child quality is approached as suggested by Statham and Chase (2010) that combine objective and subjective aspects, such as physical and non-physical. Child quality consists of 104 statements that were answered by elementary students, consisting of the following dimensions: (a) physical quality consists of 9 item (were measured by a 4-point Likert-type scale ranging from $1=$ seriously ill at once/to the hospital, $2=$ not seriously ill at once/hospitalized, $3=$ ill at once/hospitalized, 4=never); (b) quality of cognitive academic consists of six subject matters such as stocking of the average grades last 12 months or two semesters of subjects Indonesian, English, religion, mathematics, science, and social science (were measured by a ratio scale from 1-10), (c) Quality of Non-Academic Cognitive consists of 2 Item (were measured by a 2-point Likert-type scale ranging from $0=$ no, not applied, 1=yes, applied), (d) Self-esteem is composed of 15 items (were measured by a 4point Likert-type scale ranging from $1=$ never, 2=seldom, 3=sometimes, 4=very often), (e) Mental Health consists of 19 items (were measured by a 4-point Likert-type scale ranging from 1 =never, 2=seldom , 3=sometimes, 4=very often), (f) Spiritual Practice consists of 5 items (were measured by a 4-point Likert-type scale ranging from $1=$ never, $2=$ seldom, $3=$ sometimes, 4=very often), (g) Conduct behaviors consist of 18 items (were measured by a 4-point Likerttype scale ranging from $1=$ never, $2=$ seldom, 3=sometimes, 4=very often), and (h) comprises Quality of Life (Subjective) consist of 30 Item (were measured by a 4-point Likert-type scale ranging from $1=$ never, $2=$ seldom, $3=$ sometimes, $4=$ very often).

Reliability of instrumentation shows the consistency of a measuring instrument (Carmines \& Zeller, 1991). Based on Cronbach's alpha, it showed that in general the child investment was very reliable (Cronbach's alpha was 0,63 ) and child quality (Cronbach's alpha was 0,88 ) was quite reliable. The standard of setting classification of variables child investment and child quality were implemented by low (less than 50,0), medium $(50,0-75,0)$, and high (higher than 75,0). The quantitative data were analyzed using the Statistical Package for the Social Sciences (SPSS version 15.0) by applying the difference independent of T-test to analyze gender differences between boy and girl students. The Structural Equation Modeling (SEM) technique (LISREL version 8.80 Edition Student-July 2006) was used to examine the direct and indirect affect in influencing a particular endogenous variable (Joreskog, Sorbom, \& Wallentin, 2006).

\section{RESULTS}

\section{The Social, Economic, and Demographic Characteristics of Farmer Families}

It was found in Table 1 that the rate of age of father were 44,2 years for boys and 43,6 years for girls, the rate of age of mothers were 39 years for boys and 38 years for girls. The rate of education level of mother and father were not graduated from elementary school level (less than 6$)$. The rate number of family members was 6 people. The rate of monthly income per capita was IDR566.510 for boys and IDR330,490 for girls. Based on the standard of poverty line, it showed that per capita of family income below the poverty line was more than half $(59,7 \%)$ families. Overall, based on gender analysis, it proved that there was no difference between boys and girls in term of family socio economic and demographic characteristics. 
Table 1 Gender analysis of family characteristics boys and girls elementary students $(n=205)$

\begin{tabular}{|c|c|c|c|c|}
\hline \multirow{2}{*}{ Variable } & \multicolumn{2}{|c|}{ Means } & \multirow{2}{*}{$\begin{array}{l}\text { Independent T-test } \\
\text { (difference) }\end{array}$} & \multirow{2}{*}{$\begin{array}{l}\text { Significant of } \\
\text { (p) }\end{array}$} \\
\hline & Boys & Girls & & \\
\hline Age of father (years) & 44,2 & 43,6 & 0,465 & 0,642 \\
\hline Age of mother (years) & 38,6 & 37,7 & 0,782 & 0,435 \\
\hline Level education of father (years) & 5,8 & 5,5 & 1,041 & 0,299 \\
\hline Level education of mother (years) & 5,4 & 5,2 & 0,652 & 0,515 \\
\hline Number of family members (persons) & 5,5 & 5,4 & 0,695 & 0,488 \\
\hline Monthly income per capita (IDR/month) & $566.510,00$ & $330.490,00$ & 1,295 & 0,197 \\
\hline
\end{tabular}

\section{Child Investment}

The result from Table 2 showed that index of child investments were assessed by 111 items showing no significant difference between boys and girls with an average of 58,3 for boys and 56,7 for girls. Index of togetherness with mother (time) shows that there is no significant difference between boys and girls related to the time together of mother and child related to living together every day, having dinner together, worshiping, studying, playing, going to school, etc. Index of togetherness with father (time) shows no significant difference between boys and girls related to the time together father and child associated with living together every day, dinner together, worship, study, play, and school. Index of education investment shows no significant difference between boys and girls related to providing learning space, private bedroom, computers, textbooks, study desks, special savings for children, education insurance, etc.

Index of health investment shows no significant difference between boys and girls related to providing vitamins, medicines, nutritious food, health insurance, cleaning tools, etc. Index of material investment shows no significant difference between boys and girls related to saving gold, buying a house, saving, owning land, raising animals and planting trees. Index of physical protection shows no significant difference between boys and girls related to buying clothes, school supplies, getting breakfast, exercising, cutting nails, not being treated violently and given reproductive rights information. Index of psycho-social protection shows no significant difference between boys and girls related to asking questions, giving praise, appreciating, loving, religious guidance, paying attention and accompanying homework. Index of social-emotional protection shows no significant difference between boys and girls related to teaching children to do good, polite, open communication, respect, religious formation. Index of ecology protection shows no significant difference between related boys and girls taught children not to play an insecticide, introduce an insecticide device, allowed to help farming, teaches the value of life of farmers, agricultural climate, wild animals, the ways of protect plants, etc. There is no difference in the investment given to girls and boys, presumably due to parent's perceptions of the value of each child they have. As much as possible, the family treats their children equally in care and provides the same investment because parents want their children, both boys and girls to have success in life so that they make the best investment based on their abilities.

Table 2 Gender analysis of child investments $(n=205)$

\begin{tabular}{|c|c|c|c|c|}
\hline \multirow{2}{*}{ Variable and its dimensions } & \multicolumn{2}{|c|}{ Means } & \multirow{2}{*}{$\begin{array}{l}\text { Independent T-test } \\
\text { (difference) }\end{array}$} & \multirow{2}{*}{ Significant of $(p)$} \\
\hline & Boys & Girls & & \\
\hline Total of child investments & 58,3 & 56,7 & 1,080 & 0,281 \\
\hline $\begin{array}{l}\text { Special expenditure for child } \\
\text { (IDR/month) }\end{array}$ & $341.040,00$ & $342.113,00$ & $-0,026$ & 0,979 \\
\hline $\begin{array}{l}\text { Index of togetherness with mother } \\
\text { (time) }\end{array}$ & 64,8 & 63,8 & 0,400 & 0,689 \\
\hline Index of togetherness with father (time) & 48,6 & 44,2 & 1,503 & 0,134 \\
\hline Index of education investment & 35,9 & 33,7 & 1,192 & 0,235 \\
\hline Index of health investment & 63,9 & 63,0 & 0,520 & 0,604 \\
\hline Index of material investment & 21,5 & 18,7 & 1,029 & 0,305 \\
\hline Index of physical protection & 79,3 & 80,0 & $-0,534$ & 0,594 \\
\hline Index of psycho-social protection & 77,5 & 78,0 & $-0,277$ & 0,782 \\
\hline Index of social- emotional protection & 95,3 & 96,1 & $-0,521$ & 0,603 \\
\hline Index of ecology protection & 58,9 & 56,7 & 0,486 & 0,627 \\
\hline
\end{tabular}




\section{Child Quality}

The result from Table 3 showed that index of child quality was assessed by 104 items showing a significant difference between boys and girls with an average of 61,9 for boys and 64,1 for girls. Index of physical quality shows no significant difference between boys and girls related to the frequency of illness against fever/heat, colds, coughs, skin diseases, ulcers, diarrhea, lungs, typhus and injured injuries.

Index of cognitive academic quality shows a significant difference between boys and girls related to the average grades in last 12 months or two semesters of subjects in Indonesian language, English, religion, mathematics, science, and social science. Index of quality of non-academic shows no significant difference between boys and girlsin term of their achievement. Index of self-esteem shows no significant difference between boys and girls related to believe in the future, believe in yourself, be able to do something, be positive, be satisfied with yourself, be independent and feel quality.

Index of mental health shows no significant difference between boys and girls related to nervous behavior, loss of control, anger, loneliness, sadness, feeling insecure, easy to cry, hopeless, screaming and so on. Index of spiritual practices shows no significant difference between boys and girls related to obedience to worship, surrender to God, behave according to religious teachings, and participate in religious events. Index of conduct behaviors shows no significant difference between boys and girls related to getting good grades, responsible, religiously obedient, obedient to the rules, no problem, no smoking no fighting, etc.

Index of quality of life (subjective) shows no significant difference between boys and girls related to satisfaction with home, material, personal relationships, health, school, personal and the surrounding environment. The reason for the absence of differences between index of physical quality, index of non-academic achievement, index of self-esteem, index of mental health, index of spiritual practice, index of conduct behaviors and index of quality of life on child quality is thought to be due to the treatment given by parents to their children. Parents treat children the same regardless of whether the child is a boy or a girl. The parents' treatment was in the form of support, both material and non-material.
Table 3 Gender analysis of child quality ( $n=205)$

\begin{tabular}{|c|c|c|c|c|}
\hline \multirow{2}{*}{$\begin{array}{l}\text { Variable and } \\
\text { its } \\
\text { dimensions }\end{array}$} & \multicolumn{2}{|c|}{ Means } & \multirow{2}{*}{$\begin{array}{l}\text { Independent } \\
\text { T-test } \\
\text { (difference) }\end{array}$} & \multirow{2}{*}{$\begin{array}{l}\text { Signif } \\
\text { icat } \\
\text { of }(p)\end{array}$} \\
\hline & Boys & Girls & & \\
\hline $\begin{array}{l}\text { Total of child } \\
\text { quality }\end{array}$ & 61,9 & 64,1 & $-1,997$ & 0,047 * \\
\hline $\begin{array}{l}\text { Index of } \\
\text { physical } \\
\text { quality }\end{array}$ & 80,7 & 79,3 & 0,883 & 0,378 \\
\hline $\begin{array}{l}\text { Index of } \\
\text { cognitive } \\
\text { academic } \\
\text { quality }\end{array}$ & 74,6 & 76,4 & $-2,745$ & $\underset{* *}{0,007}$ \\
\hline $\begin{array}{l}\text { Index of non } \\
\text { academic } \\
\text { achievement }\end{array}$ & 5,5 & 6,2 & $-0,269$ & 0,788 \\
\hline $\begin{array}{l}\text { Index of self } \\
\text { esteem }\end{array}$ & 70,6 & 71,2 & $-0,394$ & 0,694 \\
\hline $\begin{array}{l}\text { Index of } \\
\text { mental } \\
\text { health }\end{array}$ & 74,6 & 71,6 & 1,155 & 0,250 \\
\hline $\begin{array}{l}\text { Index of } \\
\text { spiritual } \\
\text { practice }\end{array}$ & 86,1 & 87,9 & $-1,013$ & 0,312 \\
\hline $\begin{array}{l}\text { Index of } \\
\text { conduct } \\
\text { behaviors }\end{array}$ & 88,2 & 89,9 & $-0,795$ & 0,428 \\
\hline $\begin{array}{l}\text { Index of } \\
\text { quality of life } \\
\text { (subjective) }\end{array}$ & 84,6 & 83,7 & $-0,866$ & 0,387 \\
\hline
\end{tabular}

\section{Analysis of Structural Equation Modelling (SEM)}

In compiling SEM, the latent variable indicators of both child investment and child quality were simplified into three composite indicators for the purpose of fulfilling model identification. For example, the latent variable of child investments consists of 3 composite indicators, namely (1) togetherness with mother and father (time), (2) education, health, material investmensts, and (3) physical, psychosocial, social emotional, ecology protections. While the latent variable of child quality consists of 3 composite indicators, namely (1) cognitive academic quality, (2) psycho-social-spiritual (self-esteem quality, mental health, spiritual practices), and (3) quality of life. To answer the second purpose of the study, further analysis continued in Figure 1. Indicators of latent variable of child investment index consists of three indicators, while latent variable of child quality index also consists of three indicators. Based on the results in Figure 1, the model is quite fit $(\mathrm{GFI}=0,79)$. It means fit enough with the data collected. The results proved that the latent variable of child investment index has significantly positive effect on latent variable of child quality index $\left(\beta=0,15^{*}\right)$. 


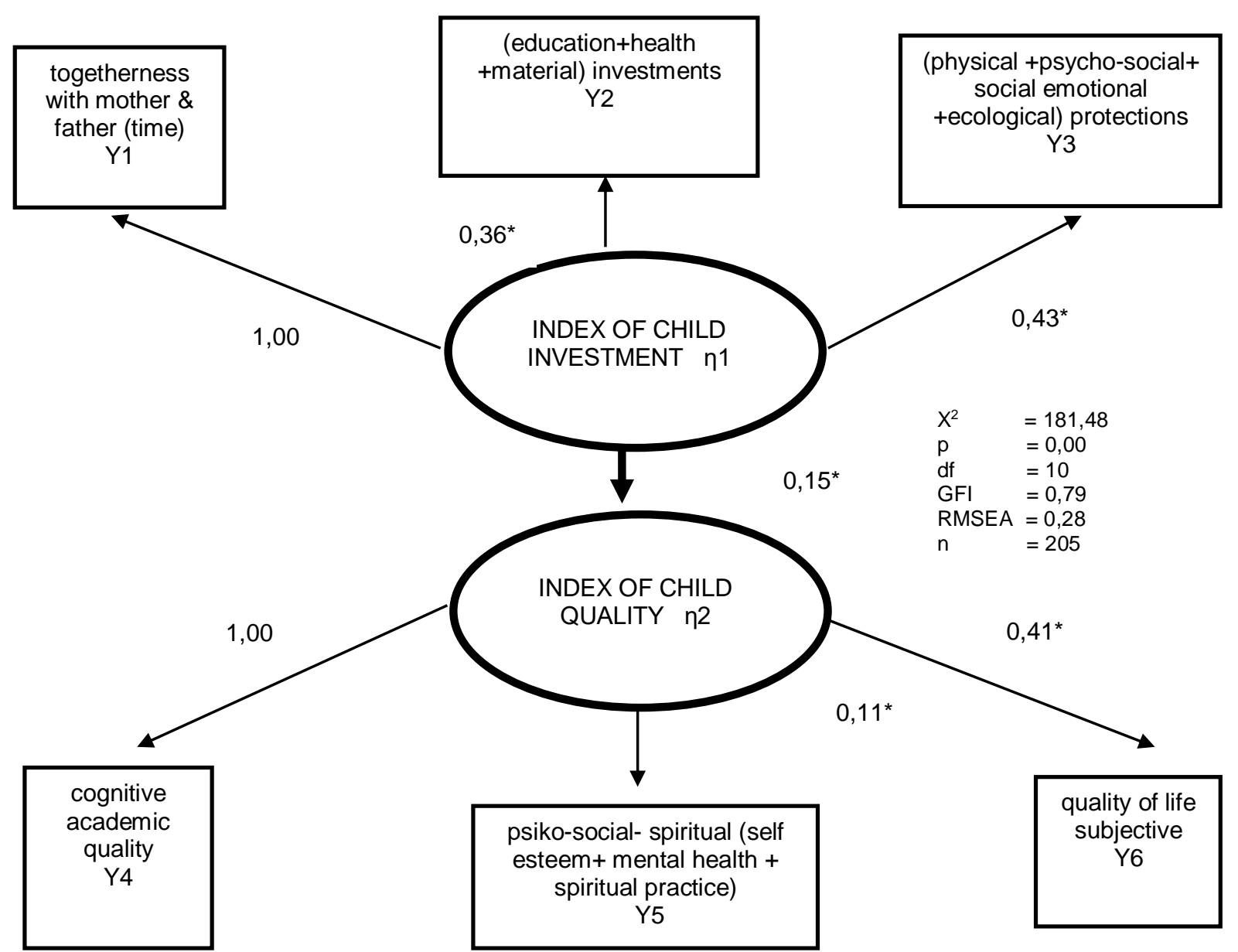

Figure 1 Validity construct of the effect of child investments towards child quality $(n=205)$

The indicators of child investment index consists of three indicators, namely: togetherness between parent and child (time) $\left(\delta=1,00^{*}\right)$, education and health investments and allocation of materials $\left(\delta=0,36^{*}\right)$, protection of children (physical, psycho-social, socialemotional, ecological) $\left(\delta=0,43^{*}\right)$. The indicators of the child quality index concist of three indicator: academic report of subjects $\left(\delta=1,00^{*}\right)$, psycho-socio-spiritual qualities (selfesteem+mental health+spiritual practices) $\left(\delta=0,11^{*}\right)$, and quality of life $\left(\delta=0,41^{*}\right)$.

The latent variable of child investments can be explained by: (1) togetherness with mother and father (time) of $(1,00)^{2}=1,00$ or 100,00 percent (2) education + health + material) investments of $(0,36)^{2}=0,1296$ or 12,96 percent, and (3) (physical + psychosocial + social emotional + ecology) protections of $(0,43)^{2}=0,1849$ or 18,49 percent. This means that the strongest indicator of the latent variable of child investment was the indicator of togetherness with mother and father, then the indicator of protections of physical-psychosocial-social emotional-ecology. The lowest indicator of the latent variable of child investment was the indicator of education-health-material investments. The latent variable of child quality can be explained by: (1) cognitive academic quality of $(1,00)^{2}=1,00$ or 100,00 percent, (2) psycho-social-spiritual (self-esteem quality + mental health + spiritual practices) of $(0,11)^{2}=$ 0,0121 or $1,21 \%$, and (3) quality of life of $(0,41)^{2}$ $=0,1681$ or 16,81 percent. This means that the strongest indicator of the latent variable of child quality was the indicator of cognitive academic quality, then the indicator of quality of life. The lowest indicator of the latent variable of child quality was the indicator of psycho-socialspiritual quality. Finally, SEM analysis results show that the latent variable of child quality is explained directly by $(0,15)^{2}$ or 2,25 percent by the latent variable of child investments.

\section{DISCUSSION}

Gender analysis on children outcomes is very unique and interenting topics in family studies. In this study, gender expectations can be applied in variables of child investments and child quality. The instruments of child 
investments and child quality were arranged comprehensively both materials and nonmaterials aspects. The family has a role as a determinant of the quality of child development and has a large role in forming the skills that children have before children enter formal school. The role of the family in educating children and investing in children determines the quality of children (Frasncesconi \& Heckman, 2016). Effective interaction that exists between parents of children is one of the determinants of the quality of children (Heckman \& Mosso, 2014). Variabel of child investmens were assessed by 111 items with dimensions of index of togetherness with mother, index of togetherness with father (time), index of education investment, index of health investment, index of material investment, index of physical protection, index of psycho-social protection, index of social-emotional protection, and index of ecology protection. Variabel of child quality was assessed by 104 items with dimensions of index of cognitive academic quality, index of physical quality, index of selfesteem, index of mental health, index of spiritual practices, index of conduct behaviors, and index of quality of life (subjective).

Based on gender analysis, results showed that there was no difference between boys and girls in total of child investments. In SEM analysis, child investments latent variabel has three indicators such as togetherness between parent (father and mother) and child (time), education and health investments and allocation of materials, and protection of children (physical, psycho-social, social-emotional, ecological). However, this result was not supported by Merton (Macionis, 1995) that mentions there is difference expectations of parents toward their girls and boys relate on labeling theory. Difference expectations could lead to difference investment on boys and girls. Men are labeled more successful if they can master the material, while women are said to be successful if they can become good mothers. Research conducted by Lareau (2011) found that parents with higher education and have a high involvement in the development of children will provide a better investment for their children. It is very important to invest in children from an early age (Aiyagari, Greenwood, \& Seshadri, 2002). The child's golden period is a period that is very important to shape the child's quality. The success or failure of developing a child's intellectual, spiritual and emotional quality depends on the ability of parents to optimize the potential of the child at this golden age. The role of parents in educating children consistently and sustainably during the golden age will determine the child's quality (Uce, 2017). Child's investment made by parents is influenced by the abilities possessed by the child. This causes the investment given by parents to their children will vary depending on the ability of children (Aiyagari et al., 2002). The benefits of investing in children from an early age are the personal abilities that children have (Heckman \& Kautz, 2012). Children's investment will be less effective if only done by parents when the child has passed the early period of their life (Heckman \& Kautz, 2014).

Here are the previous results on the importance of child investment. Planning for children's investment in the family is an important action to get quality human resources in the future. Parents can invest in children by providing educational needs, health care, and provide care through proper care for children (Rahmiati \& Puspitawati, 2013). Time is one component of investment for children (Bryant \& Zink, 2006). Good parenting of farmer parents will make children can grow and develop properly because it can reduce children's vulnerability to the physical and psychological child, especially with the help of mother who could control the situation of children with physical or mental child (Primasari \& Puspitawati, 2016). Parents invest time and money to their child based on their altruism. That investment allow their children to grow up as more productive adult (Aiyagari et al., 2002). Research conducted by Eisenhauer, Heckman, and Mosso (2015) viewed based on children's investment based on economic efficiency found that parents who attend school up to university level can motivate children to develop their skills.

Another results showed that there was significantly difference between boys and girls in variabel of child quality. Child quality latent variabel consists of three indicators such as cognitive academic quality, psycho-socialmental-spiritual practices, and quality of life. Some researchs are relevant with the results of the study. Based on national survey data from National Family Planning Coordinating Board, it showed that male adolescents have more drugrelated behaviour than girls (Nasution, Puspitawati, Rizkillah, \& Puspitasari, 2019). Santrock (2009) stated that boys are physically more aggressive, exhibit lower self-control that relate to behaviors, possess less prosocial behavior and empathy, perform lower in school performance, and less diligent in learning than girls.

Here are the previous results on child quality research. Based on research conducted by De 
Tray (1973) the quality of children was influenced by the high education of mothers. Children who have parents with high education have better academic achievement than children with parents who have low education (Dickson, Gregg, \& Robinson, 2016). Child quality was directly determined future labor market success and child well-being (CáceresDelpiano, 2006). The better the quality of children, the benefits received by children and their families in the future would be better. This was a consequence of children's investment given by parents (Chiswick, 1988). Children from larger families have lower cognitive quality than children from smaller families (Wolfe, 1982). As the number of family members increases, parents adjust the investment given to the child. These adjustments certainly affect the quality of children (Cáceres-Delpiano, 2006). An empirical investigation of trade-offs between number of children and their scholastic performance confirmed that family size directly affects children's academic achievement (Hanushek, 1992). The quality of the child increases with the greater amount of time that the mother can allocate to the child (Rahmiati \& Puspitawati, 2013). Increased family income affects demand for child quality (Schultz, 2007). Research conducted by Carneiro and Ginja (2016) found that parental income has very little impact on the quality of children. The results of research conducted by Dahl and Lochner (2012), Gayle, Golam, and Soytas (2015), and Loken, Mogstad, and Wiswall (2012) found different results, namely, parents who have high incomes can provide adequate facilities to support child development and shape the quality of children. Family income can influence children's development, this is due to poverty being related to depression, health, and the level of stress felt by parents who later affect the ability of parents to care for their children (Haushofer \& Fehr, 2014). Income shocks experienced by parents will affect parental inputs (Heathcote, Storesletten, \& Violante, 2014).

The measurements of both child investment and child quality variables in this study were approaced by a holistic measures that includes materials, and non-materials or physical and non-physical aspects. This result consistent with the concept of the welfare by Statham and Chase (2010) that 'well-being', 'life satisfaction', and 'quality of life' were often used interchangeably, and combine objective and subjective aspects of a person's life. It was understood in relation to the size of the objective and subjective such as family income, resources, education and health status, and subjective indicators such as happiness, the perception of quality of life and life satisfaction. It was also in line with the opinion of Pollard and Lee (2003), Statham and Chase (2010), Lippman (2007) that well-being has been defined by individual characteristics of an inherently positive state (happiness) on a continuum from positive to negative, such as standard of living, the absence of well-being (depression), or in a collective manner of a shared understanding. The dimensions of wellbeing consisted of physical, social, cognitive, or psychological and environmental domains. Dang and Rogers (2015) found that rural families with larger number of children would invest less in the education of school-age children. The quality of children can be seen from the skills they have in living life. These skills are obtained from the assistance and care provided by parents to children, not just from material investment provided by parents (Del Boca, Flinn, \& Wiswall, 2016).

Investment in children is also determined by fertility decisions. Parents who are better educated will plan fertility decisions well and consider the best child investment they can provide (Almlund, 2013). The quality of a child is determined by many factors, not just by a single skill such as cognitive or iq of children (Almlund, Duckworth, Heckman \& Kautz, 2011). Family involvement in raising children affects the quality of children. In parenting. Parents have different beliefs about how to raise children and can act altruistically or paternalistically (Doepke \& Zilibotti, 2017).

Finally, it was proved that latent variable of child investment index shows significantly positive effect towards latent variable of child quality index. It was interesting result from this study of rural farmer families that the investment of parents to their children has impact on the increased of child quality. Thus it can be said if the parents give to their children's commitment to provide optimal indicators such as togetherness with father-mother, educationhealth-material investment, and physicalpsycho-social-ecological protections, then it has positive effect on the quality of children consisting of indicators such as report of academic achievement, psycho-social-mentalspiritual practices, and quality of life. This result supported by Newland (2015) that child wellbeing was an impact of family well-being (FWB) and parenting quality. When families are struggling, child well-being suffers. The findings were also consistent with the opinion of Caceres-Delpiano (2006), that the quality of children affected by child investments. The 
investment of time allocated by the mother to support the child's achievement will produce good quality children (Chiswick, 1986). Furthermore, research conducted by Brown and Flinn (2007) found that investment in the quality of children is influenced by parents marital quality.

\section{CONCLUSION AND SUGGESTION}

The results showed that there was no significant difference in child investment for both boys and girls. This is thought to be caused by parents perceptions of the value of each child they have. Parents gave investment in their children is not due to the gender of the child but based on the child's abilities. Different results are shown by the variable child quality. Child quality has a significant positive difference. The results showed that the average score of quality of girls was greater than quality of boys. This is because the girls in this study have advantages in cognitive academic quality, self-esteem, spiritual practice, and conduct behavior. The results of the influence test show that child investment has a significant positive effect on child quality. This shows that the better the investment that parents give to their children, the better the quality of the children that are formed.

It is suggested that this research has to be continued with varies approaches concept of family roles and functions and with multi analysis and multi methods related to the effect of child investment and child quality to other child outcomes. The effect of family characteristics such as family with high and low social-economic status can be used as independent variables for child investments and child quality. Research is also recommended to be conducted in urban and coastal areas in order to explain the difference effect of child investment and child quality to various social economics demographics and culture of families. The research also suggest to the government to empower farmer families in prioritizing child investments through protection and parenting by increasing efforts of family well-being programs.

\section{REFERENCES}

[BPS] Badan Pusat Statistik. (2014). Profil Kemiskinan di Indonesia September 2013. Berita Resmi Statistik No. 06/01/Th. XVII. Retrieved from httpwho2014s://www.bps.go.id/website/brs _ind/ kemiskinan_02jan14.pdf.
[KEMENDIKBUD]. (2018). Statistik Pendidikan: Jumlah Putus Sekolah menurut Jenis Kelamin dan Status Sekolah tiap Provinsi. Jakarta, ID: Kementerian Pendidikan dan Kebudayaan.

[WHO] World Health Organization. (1997). WHOQOL- Measuring Quality of Life. New York, US: World Health Organization.

Aiyagari, S. R., Greenwood, J., \& Seshadri, A. (2002). Efficient investment in children. Journal of economic theory, 102(2), 290321. doi:https://doi.org/10.1006/jeth.2001. 2852.

Almlund, M. (2013). Essays on credit constraints, education, and the family (Thesis). Chicago, US: University of Chicago.

Almlund, M., Duckworth, A. L., Heckman, J., \& Kautz, T. (2011). Personality psychology and economics. In Handbook of the Economics of Education, 4, 1-181. doi:https://doi.org/10.1016/B978-0-44453444-6.00001-8.

Arifani, M. A., Sari, A. L., \& Rifkah, R. (2018). Aplikasi regulasi pembinaan anak jalanan oleh Dinas Sosial dan penanggulangan kemiskinan Kota Bandung. Jurnal IImu Sosial Dan IImu Politik, 8(2), 147-155.

Asmara, Y., \& Sukadana, I. (2017). Mengapa angka putus sekolah masih tinggi? (Studi kasus Kabupaten Buleleng Bali. E-Jurnal Ekonomi Pembangunan Universitas Udayana, 5(12), 1347-1383.

Bronfenbrenner. (1990). Alienation and the four worlds of childhood. In Muuss, Ed: Rolf. Adolescent Behavior and Society $4^{\text {th }} \mathrm{Ed}$. McGraw - Hill, US: Publishing Company.

Brown, M., \& Flinn, C. J. (2007). Investment in child quality over marital states. Wisconsi, USA: University of Wisconsin--Madison. Institute for Research on Poverty.

Brown, P. H. (2006). Parental education and investment in children's human capital in rural China. Economic Development and Cultural Change Journal, 54(4), 759-789. doi:10.1086/503582.

Bryant, W. K. (1990). The economic organization of the household. Cambridge, UK: Cambridge University Press.

Bryant, W. K., \& Zink, C. D. (2006). The economic organization of the household, second edition. New York, US: Cambridge University Press. 
Cáceres-Delpiano, J. (2006). The impacts of family size on investment in child quality. Journal of Human Resources, 41(4), 738-754. doi:10.3368/ jhr.XLI.4.738.

Carmines, E. G., \& Zeller, R. A. (1991). Reliability and validity assessment. Newbury Park, CA: Sage Publications.

Carneiro, P., \& Ginja, R. (2016). Partial insurance and investments in children. The Economic Journal, 126(596), 66-95. doi:https://doi.org/10.1111/ecoj.12421.

Cavallo, F., Zambon, A., Borraccino, A., RavenSieberer, U., Torsheim, T., \& Lemma, P. (2006). Girls growing through adolescence have a higher risk of poor health. Quality of Life Research, 15(10), 1577-1585. doi:https://doi.org/10.1007/s11136-0060037-5c.

Chiswick, B. R. (1986). Labor supply and investment in child quality: A study of Jewish and Non-Jewish women. The Review of Economics and Statistics, 68(4), 700. doi: $10.2307 / 1924532$.

Chiswick, B. R. (1988). Differences in education and earnings across racial and ethnic groups: Tastes, discrimination, and investments in child quality. The Quarterly Journal of Economics, 103(3), 571-597. doi:10.2307/1885546.

Chozin, M. A., Sumardjo, Poerwanto, R., Purbayanto, A., Khomsan, A., Fauzi, A., Toharmat, T., Hardjanto, \& Seminar K. B (Ed) (1980). Pembangunan perdesaan dalam rangka peningkatan kesejahteraan masyarakat: Pemikiran guru besar perguruan tinggi badan hukum milik negara. Bogor, ID: IPB Press.

Coontz, S. (2000). Historical perspectives on family studies. Journal of Marriage and Family, 62(2), 283-29. doi:10.1111/j.17413737.2000.00283.x.

Dahl, G. B., \& Lochner, L. (2012). The impact of family income on child achievement: Evidence from the earned income tax credit. American Economic Review, 102(5), 1927-1956. doi:10.1257/aer.102.5.1927.

Dang, H. A. H., \& Rogers, F. H. (2015). The decision to invest in child quality over quantity: Household size and household investment in education in Vietnam. The World Bank Economic Review, 30(1), 105142. doi:10.1093/wber//hv048.
De Tray, D. N. (1973). Child quality and the demand for children. Journal of Political Economy, 81(2), 70-95. doi:10.1086 /260154.

Del Boca, D., Flinn, C., \& Wiswall, M. (2016). Transfers to households with children and child development. The Economic Journal, 126(596), 136-183. doi:10.1111/ecoj. 12340.

Dickson, M., Gregg, P., \& Robinson, H. (2016). Early, late or never? When does parental education impact child outcomes?. The Economic Journal, 126(596), 184-231. doi:10.1111/ecoj.12356.

Doepke, M., \& Zilibotti, F. (2017). Parenting with style: Altruism and paternalism in intergenerational preference transmission. Econometrica, 85(5), 1331$1371 . \quad$ doi:https://doi.org/10.3982/ ECTA14634

Eisenhauer, P., Heckman, J. J., \& Mosso, S. (2015). Estimation of dynamic discrete choice models by maximum likelihood and the simulated method of moments. International economic review, 56(2), 331-357. doi:https://doi.org/ 10.1111/iere.12107.

Enggarani, N. S. (2015). Upaya pengendalian preventif kekerasan anak yang berdampak pada perilaku menyimpang. Prosiding Seminar Nasional Psikologi UMS, 252260.

Francesconi, M., \& Heckman, J. J. (2016). Child development and parental investment: Introduction. The Economic Journal, 126(596), 1-27. doi:https://doi.org/ 10.1111/ecoj.12388.

Gayle, G. L., Golan, L. and Soytas, M. A. (2015). What accounts for the racial gap in time allocation and intergenerational transmission of human capital', St. Louis Federal Reserve Working Paper.

Glewwe, P., \& Jacoby, H. (1994). Student achievement and schooling choice in lowincome countries: Evidence from Ghana. The Journal of Human Resources, 29(3), 843. doi:10.2307/146255.

Greenberger, E., \& Goldberg, W. A. (1989). Work, parenting, and the socialization of children. Developmental Psychology, 25(1), 22- 35.

Hampel, P. (2007). Brief report: Coping among Austrian children and adolescents. Journal of Adolescence, 30(5), 885-890. 
doi:https://doi.org/10.1016/j.adolescence.2 007.04.005.

Hanushek, E. A. (1992). The trade-off between child quantity and quality. Journal of Political Economy, 100(1), 84-117. doi:10.1086/261808.

Haris, J. C, \& Liebert, R. M. (1992). The child: $A$ contemporary view of development. Englewood Cliffs, USA: Prentice Hall.

Haushofer, J., \& Fehr, E. (2014). On the psychology poverty. Science, 344(6186), 862-867. doi:10.1126/science.1232491.

Heathcote, J., Storesletten, K., \& Violante, G. L. (2014). Consumption and labor supply with partial insurance: An analytical framework. American Economic Review, 104(7), 2075-2126. doi:10.1257/aer.104.7.2075.

Heckman, J. J. \& Kautz, T. (2014). Fostering and measuring skills: Interventions that improve character and cognition', in (Heckman, J.J., Humphries, J.E. and Kautz, T. (eds.), The Myth of Achievement Tests: The GED and the Role of Character in American Life, pp. 341-430. Chicago, IL: University of Chicago Press.

Heckman, J. J., \& Kautz, T. (2012). Hard evidence on soft skills. Labour economics, 19(4), 451-464. doi:https://doi.org/10.1016 /j.labeco.2012.05.014.

Heckman, J. J., \& Mosso, S. (2014). The economics of human development and social mobility. Annual Review of Economics, 6(1), 689-733. doi:10.1146/ annurev-economics-080213-040753.

Hendra, J. R. (2018). Kajian perspektif gender pada pola asuh orang tua bagi perkembangan anak di Desa Batu Merah Kota Ambon. FIKRATUNA: Jurnal Penelitian Sosial Keagamaan, 7(2),1-18.

Joreskog, K. G., Sorbom, D., \& Wallentin, F. Y. (2006). Latent variable scores and observation residuals. Swedia, SE: Uppsala University.

Kang, C. (2010). Family size and educational investment in children: Evidence from private tutoring expenditure in South Korea. Oxford Bulletin of Economics and Statistics, 73(1), 59-78. doi:10.1111/j. 1468-0084.2010.00607.x.

Kilpatrick, A. C., \& Holland, T. P. (2003). Working with families. Boston, USA: Allyn, \& Bacon
Klein, D. M., \& White, J. M. (1996). Family theories an introduction. Thousand Oaks, UK: Sage Publications.

Lareau, A. (2011). Unequal childhoods: Class, race, and family life (2nd ed). Berkeley, CA: University of California Press.

Lippman, L. H. (2007). Indicators and indices of child well-being: A brief american history. Social Indicators Research, 83, 39-53. doi:10.1007/5 11205-006-9058-2.

Loken, K. V., Mogstad, M., \& Wiswall, M. (2012). What linear estimators miss: The effects of family income on child outcomes. American Economic Journal: Applied Economics, 4(2), 1-35. doi:10.1257/app.4.2.1.

Lucas, R. E. (1988). On the mechanics of economic development. Journal of Monetary Economics. 22(1), 3-42. doi:https://doi.org/10.1016/0304-3932(88 )90168-7.

Macionis, J. J. (1995). Annotated instructor's edition sociology (5th Ed). New Jesey, USA: Prentice Hall, Englewood Cliffts.

Manupahi, E., Goni, S. Y. V. I., \& Pogoh, H. W. (2016). Kajian kekerasan dalam rumah tangga terhadap psikologi anak di Desa Soakonora Kecamatan Jailolo Kabupaten Halmahera Barat. E-Journal: Acta Diurna, 5(1), 1-15.

Michel, G., Bisegger, C., Fuhr, D. C., \& Abel, T. (2009). Age and gender differences in health-related quality of life of children and adolescents in Europe: A multilevel analysis. Qual Life Res, 18, 1147-1157. doi:https://doi.org/10.1007/s11136-0099538-3.

Nasution, S. L., Puspitawati, H., Rizkillah, R., \& Puspitasari, M. D. (2019). Pengaruh pengetahuan remaja tentang Napza dan HIV serta pengetahuan orang tua tentang program pembangunan keluarga terhadap perilaku penggunaan Napza pada remaja. Jurnal IImu Keluarga dan Konsumen, 12(2), 100-113. doi:http://dx.doi.org/ 10.24156/jikk.2019.12.2.100.

Newland, L. A. (2015). Family well-being, parenting, and child well-being: Pathways to healthy adjustment. Clinical Psychologist.

Nolen-Hoeksema, S., \& Girgus, J. S. (1994). The emergence of gender differences in depression during adolescence. Psychological Bulletin, 115(3), 424-443. 
doi:https://doi.org/10.1037//00332909.115.3.424.

Pollard, E. L, \& Lee P. D. (2003). Child wellbeing: A systematic review of the literature. Social Indicators Research, 61(1), 59-78.

Ponczek \& Souza. (2011). New evidence of the causal effect of family size on child quality in developing country. Sao Paulo, PT: Portugis.

Popkova, E. G., Chechina, O. S., \& Abramov, S. A. (2015). Problem of the human capital quality reducing in conditions of educational unification. Mediterranean Journal of Social Sciences, 6(3 S6), 95-95. doi:10.5901/mjss.2015.v6n3s6p95.

Primasari, D., \& Puspitawati, H. (2016). Child vulnerability and well-being among farmer families. Journal of Family Sciences, 01(02), 25-43.

Puspitawati, H., Sarma, M., \& Yuliati, L. N. (2015). The family research on coping strategies, child investment, child quality and family well-being among highland farmers in Indonesia. Institut Pertanian Bogor, ID: IPB Press.

Rahmiati, T. S. A., \& Puspitawati, H. (2013). Hubungan antara investasi dan kualitas anak usia sekolah pada keluarga petani. Jurnal IImu Keluarga dan Konsumen, 6(3), 154-162. doi:https://doi.org/10.24156/jikk. 2013.6.3.154.

Santrock, J. W. (2009). Child development $\left(12^{\text {th }}\right.$ Ed.). New York, US: Mc Graw Hill.

Satriani, R. A., \& Muis, T. (2013). Studi tentang perdagangan manusia pada remaja putri jenjang sekolah menengah di Kota Surabaya. Jurnal BK Unesa, 4(1), 67-78.

Schultz, T. P. (2007). Chapter 52 population policies, fertility, women's human capital, and child quality. Handbook of
Development Economics, 32493303. doi:10.1016/s1573-4471(07)040521.

Schultz, T. W. (1981). Economics of the family: Marriage, children, and human capital. Chicago, US: University of Chicago Press.

Schwartz, M. A., \& Scott B. M. (1994). Marriages and families: Diversity and change. New Jersey, US: Prentice - Hall Inc.

Skidmore, W. (1979). Theoretical thinking in sociology ( $2^{\text {nd }}$ Ed). New York, US: Cambridge University Press.

Spencer, M., \& Inkeles, A. (1982). Foundations of modern sociology ( $\left.3^{\text {rd }} \mathrm{Ed}\right)$. New Jersey, USA: Prentice Inc.

Statham, J., \& Chase, E. (2010). Childhood well-being: A brief overview (Briefing paper 2). London, UK: Childhood Well-being Research Centre.

Sunarti, E. (2004). Mengasuh dengan hati: Tantangan yang menyenangkan. Jakarta, ID: PT Elex Media Komputindo.

Uce, L. (2017). The golden age: Masa efektif merancang kualitas anak. Bunayya: Jurnal Pendidikan Anak, 1(2), 77-92.

Villa, Z. M., Sunarti, E., \& Muflikhati, I. (2020). Perilaku investasi anak menentukan peran nilai anak dalam kesejahteraan anak. Jurnal IImu Keluarga dan Konsumen, 13(2), 151-162. doi:http://dx.doi.org/ 10.24156/jikk.2020.13.2.151.

Winton, C. A. (1995). Frameworks for studying families. Connecticut, US: The Duskin Publishing Group, Inc.

Wolfe, J. R. (1982). The impact of family resources on childhood IQ. The Journal of Human Resources, 17(2), 213-235. doi:10.2307/145470. 